\title{
Erratum to: Binge drinking and labor market success: a longitudinal study on young people
}

\author{
Shao-Hsun Keng • Wallace E. Huffman
}

Published online: 8 January 2010

(C) Springer-Verlag 2009

\section{Erratum to: J Popul Econ \\ DOI 10.1007/s00148-005-0053-8 \\ DOI 10.1007/s00148-005-0043-x}

This article has been published twice: one was published on pages $35-54$ of the 2007 Volume 20 Issue 1 while the other was published on pages 303-322 of the 2010 Volume 23 Issue 1.

The online versions of the original articles can be found at http://dx.doi.org/10.1007/s00148-005-0053-8 and http://dx.doi.org/10.1007/s00148-005-0043-x.

S.-H. Keng $(\varangle)$

Department of Applied Economics, National University of Kaohsiung,

700 Kaohsiung University Road, Kaohsiung, 811, Taiwan

e-mail: shkeng@nuk.edu.tw

W. E. Huffman

Department of Economics, Iowa State University, Ames, IA 50011, USA

e-mail: whuffman@iastate.edu 